\title{
Studies on Dinonylnaphthalene Sulphonic Acid as Liquid Ion Exchanger for Radioactive Liquid Waste Disposal (Part I)
}

\author{
Sung-Mao Wang, Min-Nan Chen, Chia-Lian Tseng, and Pao-Shan Weng \\ Institute of Chemistry and Health Physics Section, \\ National Tsing Hua University, \\ Hsinchu, Taiwan 300, Republic of China \\ Received May 29, 1973
}

\begin{abstract}
A preliminary study on the treatment of radioactive liquid waste by dinonylnaphthalene sulphonic acid as liquid cation exchanger is given. Some fundamental studies on the selectivity coefficients and the gamma-radiation stability of dinonylnaphthalene sulfonic acid are presented and discussed. The selectivity coefficient is found to be the highest for the trivalent metal ions, and then the monovalent and the divalent metal ions in sequence; for the rare earth series the selectivity coefficient is decreasing with increasing atomic number. Further study on the radioactive waste disposal will be continued in Part II.
\end{abstract}

\section{Introduction}

Dinonylnaphthalene sulphonic acid (HD) and its sodium soap ( $\mathrm{NaD}$ ) form micelles in non-polar organic solvents ${ }^{1,2)}$, and serve as analogues of cross-linked resinous strongacid cation-exchangers ${ }^{3) \sim 7}$. Since HD and $\mathrm{NaD}$ give stronger extraction of metal from the aqueous phase to the organic phase by a factor of more than $10^{3}$, when compared with the same formal concentration of the chelating extractant, thenoyltrifluoroacetylacetone $^{8)}$, it is our attempt to investigate the feasibility and capability of using the low-cost HD as a liquid ion-exchanger for radioactive waste disposal including both medium-and high-level liquid wastes.

The selectivity of HD for some monovalent, divalent and trivalent cations, and the radiation stability of this reagent have been investigated in this work. The preliminary study shows that the method using HD as an cation-exchanger would be a simplest yet efficient one for the treatment of radioactive wastes.

\section{Experimental}

Materials Dinonylnaphthalene sulphonic acid was obtained as a 39 per cent solution in $n$-heptane from R.T. Vanderbilt Co., Inc., USA. Its stock solution was analysed by shaking with a known volume of the solution with standard potassium hydroxide, followed by titration of an aliquot of the aqueous phase with standard hydrochloric acid $^{31}$. The $n$-hexane and all the other organic solvents were of C.P. grade.

Preparation of radioisotopes In this investigation most radioactive wastes were artificially generated in the 1-MW Tsing Hua Open-pool Reactor (THOR) by irradiating high purity metals or oxides in the pneumatic tube system, and prepared in the form of perchlorate by dissolving the irradiated samples in 1 liter of $0.1 \mathrm{M}$ perchloric acid solution. The purity of radioactive nuclides was determined by a multichannel pulse height analyzer.

Selectivity measurement As an ion exchanger, the organic phase contained HD in the concentrations of $10^{-3}$ to $10^{-4}$ formula weight per liter, and was pre-equilibrated with an equal volume of $0.3 \mathrm{M}$ perchloric acid. The aqueous phase normally was prepared to contain metal ion of radioactive waste in the concentrations of $10^{-5}$ to $10^{-6} \mathrm{M}$ with various concentrations of perchloric acid solution. Equal volumes $(10 \mathrm{~m} l)$ of 
aqueous and organic phases were mixed in a glass-stoppered Erlenmeyer flasks and shaken for 2 hours, and then allowed to settle for 1 hour. A $1 \mathrm{~m} l$ aliquot of each phase was removed, and the activity of the metal ion in each phase was measured with a gamma scintillation counter. The distribution coefficient is defined as:

$$
K_{d}=\frac{\begin{array}{c}
\text { activity of tracer metal in } \\
\text { organic phase }
\end{array}}{\begin{array}{c}
\text { activity of tracer metal in } \\
\text { aqueous phase }
\end{array}}
$$

Since the micelle formation by $H D$ in organic media has been demonstrated ${ }^{1)}$, the HD in organic phase may exist as polymer, (HD) $)_{x}$, where the subscript $x$ indicates the number of aggregation. The exchange reaction between metal ion $M^{+b}$ and $H D$ has been proposed as follows ${ }^{3), 4)}$ :

$$
M_{a}^{+b}+(H D)_{x, o}=M\left(H_{x-b} D_{x}\right)_{o}+b H_{a}{ }^{+}(1)
$$

where the subscripts $a$ and $o$ denote the aqueous and organic phase, respectively, and $b$ is the number of valence. The corresponding mass action law can be expressed, in terms of concentrations rather than activities, as:

$$
\frac{\left[M\left(H_{x-b} D_{x}\right)\right]_{0}}{\left(M^{+b}\right)_{a}}=K \frac{\left.[H D)_{x}\right]_{o}}{\left(H^{+}\right)_{a}^{b}} .
$$

If $M^{+b}$ is the only $M$ species of importance in the aqueous phase, then the ratio $\frac{\left[M\left(H_{x-b} D_{x}\right)\right]_{0}}{\left(M^{+b}\right)_{a}}$ may be replaced by the distribution coefficient, $K_{d}$, to yield

$$
K_{d}=K \frac{\left[(H D)_{x}\right]_{o}}{\left(H^{+}\right)_{a}^{b}}
$$

The $H D$ dependency is of first order regardless of the value of $b$ in $M^{+b}$, while the $\mathrm{H}^{+}$dependency is of second order for $\mathrm{M}^{+2}$ and of third order for $M^{+3}$.

Since the critical range of micelle formation of $\mathrm{HD}$ was estimated to be $10^{-6} \mathrm{~F}$ to $10^{-7} \mathrm{~F}^{1)}$, and the aggregation number is independent of concentration in low-polarity solvents, the molecules of HD are predominately in the associated states as non-dispersed micelles. Thus the molar concentration of micelles having an aggregation number $x$ will be of $(H D) / x$, where $(H D)$ is the concentration of $\mathrm{HD}$ in formality.
The size of micelle varies with the solvent properties yet it is almost constant in a given solvent. Thus, it is convenient to define the selectivity coefficient of ion exchange in the system $M^{+b}-H^{+}$by $H D$ as $K_{H^{+}}^{M^{+b}}=K / x$, where $K$ is the concentration equilibrium quotient in Eq. ( 1 ). Thus Eq. ( 3 ) can be rearranged to yield

$$
K_{H^{+}}^{M^{+b}}=\frac{K}{x}=\frac{K_{d}\left(H^{+}\right)_{a}^{b}}{(H D)_{o}} .
$$

The distribution coefficients of ${ }^{46} \mathrm{Sc},{ }^{64} \mathrm{Cu}$, ${ }^{65} \mathrm{Zn},{ }^{86} \mathrm{Rb},{ }^{90} \mathrm{Y},{ }^{137} \mathrm{Cs},{ }^{140} \mathrm{La},{ }^{144} \mathrm{Ce},{ }^{142} \mathrm{Pr},{ }^{147} \mathrm{Nd}$, ${ }^{153} \mathrm{Sm},{ }^{152,4} \mathrm{Eu},{ }^{159} \mathrm{Gd},{ }^{160} \mathrm{~Tb},{ }^{165} \mathrm{Dy},{ }^{166} \mathrm{Ho},{ }^{171} \mathrm{Er}$, ${ }^{170} \mathrm{Tm},{ }^{175} \mathrm{Yb},{ }^{177} \mathrm{Lu},{ }^{204} \mathrm{Tl}$, and ${ }^{241} \mathrm{Am}$ were measured by varying the concentration of HD in organic phase, and then by varying the hydrogen ion concentration in aqueous phase at $28 \pm 1^{\circ} \mathrm{C}$. Their selectivity coefficients were evaluated from the distribution coefficients.

Radiation stability measurement The effects of large gamma dosage by a $600 \mathrm{Ci}$ ${ }^{60} \mathrm{Co}$ source on $\mathrm{HD}$ were investigated by measuring the distribution coefficients of ${ }^{60} \mathrm{Co}$ between organic phase containing $2.2 \times$ $10^{-3} \mathrm{~F}$ HD and aqueous phase containing $1.22 M \mathrm{HClO}_{4}$.

Preliminary study of radioactive waste treatment In order to find the better conditions for HD to remove radioactive elements in the aqueous solution by cation exchange, the following experiments were carried out: (1) extraction of $\mathrm{Co}(\mathrm{II})$ with various concentrations of carrier $\mathrm{CoCl}_{2}$ from the aqueous solution of different concentration of hydrochloric acid into $0.1 \mathrm{~F}$ HD solution in toluene and (2) extraction of $\mathrm{Co}(\mathrm{II})$ from various concentration of aqueous $\mathrm{CoCl}_{2}$ solution into various concentration of $\mathrm{HD}$ in toluene.

\section{Results and Discussion}

\section{Selectivity of HD}

A plot of $\log K_{d}$ versus $\log (H D)$ for all elements regardless of the value of $b$ in $M^{+b}$ yielded straight lines with slope of unity as expected from Eq. (1), and a plot of $\log K_{c}$ versus $\log \left(H^{+}\right)$gave straight lines with slopes of $-1,-2$, and -3 for $M(I), M(\mathbb{I})$, 
and $M(\mathbb{I I I})$, respectively. From these plots and the distribution coefficients, the selectivity coefficients were calculated, and the results are summarized in Tables 1 and 2 . The precision attained in distribution coefficients was generally better than $\pm 2 \%$.

Table 1 Selectivity coefficients of HD in $n$-hexane for various metal ions, at $28^{\circ} \mathrm{C}$

\begin{tabular}{l|c|c}
\hline Metal ions & $\begin{array}{c}\text { Slope of } \log K_{d} \\
\text { vs. } \log \left(H^{+}\right) \text {plot }\end{array}$ & $K_{H^{+}}^{M^{b}}$ \\
\hline $\mathrm{Cs}(\mathrm{I})$ & -1 & 10.9 \\
$\mathrm{Rb}(\mathrm{I})$ & -1 & 2.6 \\
$\mathrm{Tl}(\mathrm{I})$ & -1 & 12.9 \\
\hline $\mathrm{Mn}(\mathbb{I I})$ & -2 & $3.3^{*}$ \\
$\mathrm{Co}(\mathrm{II})$ & -2 & $3.2^{*}$ \\
$\mathrm{Cu}(\mathbb{I})$ & -2 & 4.3 \\
$\mathrm{Zn}(\mathbb{I I})$ & -2 & 4.2 \\
\hline $\mathrm{Fe}(\mathbb{I I I})$ & -3 & $20.4^{*}$ \\
$\mathrm{In}(\mathbb{I I I})$ & -3 & $35.1^{*}$ \\
$\mathrm{Sc}(\mathbb{I I})$ & -3 & 45.9 \\
$\mathrm{Y}(\mathbb{I I})$ & -3 & 67.7 \\
$\mathrm{La}(\mathbb{I I})$ & -3 & 319 \\
$\mathrm{Am}(\mathbb{I I})$ & -3 & 557 \\
\hline
\end{tabular}

* The values calculated from the data in ref. (3).

Table 2 Selectivity coefficients of HD in $n$-hexane for rare earth series, at $28^{\circ} \mathrm{C}$

\begin{tabular}{|c|c|c|}
\hline Metal ions & $\begin{array}{l}\text { Slope of } \log K_{d} \\
\text { vs. } \log \left(H^{+}\right) \text {plot }\end{array}$ & $K_{H^{+}}^{M^{+b}}$ \\
\hline $\mathrm{La}(\mathbb{I})$ & -3 & 319 \\
\hline $\mathrm{Ce}(\mathbb{I I I})$ & -3 & 112.2 \\
\hline $\operatorname{Pr}($ III $)$ & -3 & 93.0 \\
\hline $\mathrm{Nd}(\mathbb{I I I})$ & -3 & 37.2 \\
\hline $\mathrm{Sm}($ III $)$ & -3 & 72.7 \\
\hline $\mathrm{Eu}(\mathbb{I I})$ & -3 & 62.4 \\
\hline $\operatorname{Gd}(\mathbb{I I})$ & -2 & - \\
\hline $\mathrm{Tb}(\mathbb{1 1})$ & -3 & 86.0 \\
\hline Dy $(\mathbb{I I})$ & -3 & 63.4 \\
\hline $\mathrm{Ho}(\mathrm{III})$ & -3 & 73.0 \\
\hline $\operatorname{Er}(\mathbb{I I})$ & -3 & 63.0 \\
\hline $\operatorname{Tm}(\mathbb{I I})$ & -3 & 43.0 \\
\hline $\mathrm{Yb}(\mathbb{I I})$ & -3 & 50.4 \\
\hline $\mathrm{Lu}(\mathbb{I})$ & -3 & 57.4 \\
\hline
\end{tabular}

It is obvious from Tables 1 and 2 that acid dependency for the most metal ions is as expected from their values of $b$ in $M^{+b}$ except $\mathrm{Gd}(\mathbb{I I})$. $\mathrm{Gd}(\mathbb{I I})$ may be extracted by HD into organic phase with a net charge of +2 , probably in the form of $\mathrm{GdOH}^{+2}$. The selectivity coefficient is found to be the highest for the trivalent metal ions, and then for the monovalent and the divalent metal ions in sequence. If the value of $x$ in $(H D)_{x}$ does not vary appreciably, the dependence of the magnitude of selectivity coefficient on the charge of the metal ion is reasonable.

The selectivity coefficient in the trivalent rare earth series seems to decrease with increasing atomic number and with decreasing size of ionic radius because of the effect of lanthanide contraction.

\section{Radiation stability}

The gamma radiation effect on the distribution coefficient of ${ }^{60} \mathrm{Co}$ between $2.2 \times 10^{-3}$ F HD in $n$-hexane and $1.22 \mathrm{M} \mathrm{HClO}_{4}$ solution is given in Table 3.

Table 3 Radiation effect on distribution coefficients $\mathrm{HD}$ in $n$-hexane= $2.2 \times 10^{-3} \mathrm{~F}, \quad \mathrm{HClO}_{4}=1.22 \mathrm{M}$

\begin{tabular}{c|c|c|c}
\hline \multirow{2}{*}{$\begin{array}{c}\gamma \text { Dose } \\
\left(10^{6} \mathrm{R}\right)\end{array}$} & \multicolumn{2}{|c|}{ Activity $(\mathrm{cpm} / \mathrm{m} l)$} & \multirow{2}{*}{$K_{d}$} \\
\cline { 2 - 3 } & $\begin{array}{c}\text { Organic } \\
\text { phase }\end{array}$ & $\begin{array}{c}\text { Aqueous } \\
\text { phase }\end{array}$ & \\
\hline 0 & 12,955 & 6,179 & 2.10 \\
0.34 & 12,961 & 6,111 & 2.12 \\
0.68 & 12,964 & 6,184 & 2.10 \\
1.36 & 12,668 & 5,915 & 2.14 \\
2.72 & 13,120 & 6,253 & 2.10 \\
4.08 & 12,958 & 6,199 & 2.09 \\
\hline
\end{tabular}

It is seen from Table 3 that the gammaradiation shows no effect on $H D$ at least up to $4.08 \times 10^{6} \mathrm{R}$. Thus, the HD could suffer radiation damage and should be used in treating high-level radioactive wastes.

\section{Preliminary treatment of radioactive wastes}

The results of treatment in terms of the percentage of activity removed from the 


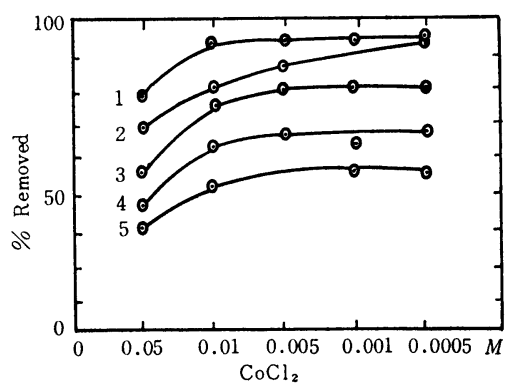

Fig. 1 Extraction of ${ }^{60} \mathrm{Co}$ with different concentrations of carrier $\mathrm{CoCl}_{2}$ from aqueous solution of various $\mathrm{HCl}$ concentrations in to $0.1 \mathrm{~F} \mathrm{HD}$ in toluene solution: (1) $0.1 M$, (2) $0.2 M$, (3) $0.3 M$, (4) $0.4 M$, and (5) $0.5 M$ $\mathrm{HCl}$.

acidic radioactive waste solutions by use of HD in toluene are shown in Figs. 1 and 2.

In the extraction of metal ion with $\mathrm{HD}$ from acid solution, emulsion is formed if the concentration of acid is lower than that of HD. The higher concentration of acid, however, would depress the extraction ability of HD as can be seen in Fig. 1. The optimum condition to remove most of $\mathrm{Co}(\mathbb{I})$ ion from $0.01 \mathrm{M}$ or less $\mathrm{CoCl}_{2}$ solution is of $0.1 \mathrm{~F} \mathrm{HD}$ in organic solvent with $0.1 \mathrm{M}$ or less $\mathrm{HCl}$ in aqueous solution. In general, the concentration of HD much larger than that of cation multiplied by the number of valence is required for the complete removal of the cation according to Eq. (1).

In the presence of large amount of $\mathrm{CoCl}_{2}$, even in the absence of acid in aqueous solution, no emulsion is formed by $\mathrm{HD}$, and the exchange ability seems to be better than the case in that the acid is present. For the extraction of $0.01 \mathrm{M} \mathrm{CoCl}_{2}$, a less than $0.05 \mathrm{~F}$ of $\mathrm{HD}$ can remove about $98 \% \mathrm{Co}$ (II) ion from the aqueous solution as shown in Fig. 2.

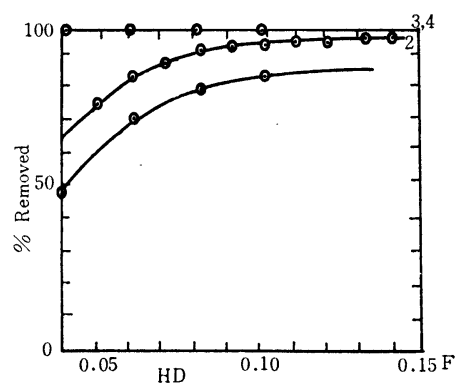

Fig. 2 Extraction of ${ }^{60} \mathrm{Co}$ from aqueous solution of various $\mathrm{CoCl}_{2}$ concentrations into various concentrations of HD in toluene. (1) $0.1 \mathrm{M}$, (2) $0.05 \mathrm{M}$, (3) $0.01 M$, (4) $0.005 \mathrm{M} \mathrm{CoCl}_{2}$.

\section{Acknowledgment}

This work was supported by the International Atomic Energy Agency under Contract No. $640 /$ RB.

\section{References}

1) S. Kaufman and C.R. Singleterry: $J$. Colloid Sci., 10, 139 (1955); ibid., 12, 465 (1957)

2) S. Kaufman: J. Colloid Sci., 17, 231 (1962)

3) J.M. White, P. Tang and N.C. Li: J. Inorg. Nucl. Chem., 14, 255 (1960)

4) J.M. White, P. Kelly and N.C. Li: J. Inorg. Nucl. Chem., 16, 337 (1961)

5) G.R. Choppin and P.J. Unrein: J. Inorg. Nucl. Chem., 25, 387 (1963)

6) G.E. Boyd, S. Lindenbaum, and Q.V. Lavson: Inorg. Chem., 3, 1437 (1964)

7) S.M. Wang and N.C. Li: J. Inorg. Nucl. Chem., 27, 2093 (1965)

8) S.M. Wang and N.C. Li: J. Inorg. Nucl. Chem., 28, 1091 (1966) 
要旨

\section{放射性廃液処理における液体イオン交換体としての \\ ジノニルナフタリンスルホン酸の研究（第1 報）}

王 松茂, 陳 敏男, 曾 家完, 翁 宝山

国立清華大学化学研究所括よび保健物理組

中華毛国，台浮省，新竹门j

ジノルナフタリンスルホン酸を放射性廃液の处理において液体陽イオン交換体として利用する ことの基礎的研究を行なった。20数種の元素について分配係数を測定して，選択係数を求めた。選 択係数は 3 価の金属イオンに対してもっとも高く,ついで 1 価， 2 価の金属イオンの順であった。 希土類元素に対しては，選択係数は原子番号の増加とともに減少する。また $\gamma$ 線照射に対するジノ ニルナフタリンスルホン酸の安定性について検討を行なったが少なくとも $4.08 \times 10^{6} \mathrm{R}$ をは影響 がなかった。 